\title{
CURRENT TECHNOLOGICAL STATUS OF VIETNAMESE ENTERPRISES WITH THE REQUIREMENTS OF INTERNATIONAL INTEGRATION
}

\author{
Huong Le Thi Mai \\ University of Finance and Marketing, Ho Chi Minh, Viet Nam \\ Hung Tran Van \\ Vietnam National University of Forestry, Đong Nai, Vietnam
}

The article is based on the secondary data sources collected from the agency departments in order to describe the current technological status of Vietnamese enterprises and their compliance with the requirements of international integration. The research results show that the technological level of Vietnamese enterprises is mostly low and it is much lower as compared with the selected members of the ASEAN. Against this background, the article proposes some recommendations that contribute to promoting the role of science and technologies in business operations.

Keywords: technology, enterprises, international integration, Vietnam.

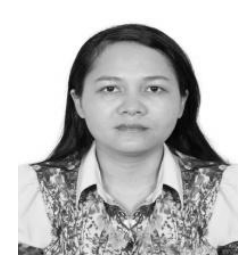

Huong Le Thi Mai

$\mathrm{PhD}$ ("The technological current status of Vietnamese enterprises with the requirements of international integration")

Lecturer in Finance, University of Finance and Marketing, Ho Chi Minh, Viet Nam

Science interests -financial sector, banking sector, SMEs functioning and government support, ecological economics, environmental issues of economic development and corporate social responsibility.

E-mail: : maihuongbd@gmail.com

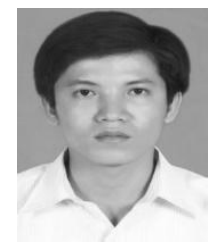

\section{Hung Tran Van}

$\mathrm{PhD}$ ("The technological current status of Vietnamese enterprises with the requirements of international integration")

Lecturer Faculty of Economics, Vietnam National University of Forestry, Southern Campus, Dong Nai Province, Viet Nam

Research interests - markets of agricultural products, SMEs functioning and government support, ecological economics, environmental issues of economic development and corporate social responsibility, financial management. Published more than 20 papers in International journals, member of editorial board of International journals.

E-mail: tranhungln2@gmail.com 


\section{Introduction}

Due to the growing role of the integration trends in the international economy, especially since Vietnam's participation in economic and trade organizations such as the WTO or the AEC, Vietnamese enterprises have been facing many opportunities as well as challenges concerning this integration. In particular, the science and technology input is one of the most important factors that help enterprises strengthen their internal capacity and increase their competitiveness in domestic and foreign markets (Dao Thanh Truong, 2015]. According to the report of the World Economic Forum (WEF) as of 2015-2016, by the availability of new technologies Vietnamese enterprises ranked only 112 out of 140 countries. This index is 42 ranks lower than that of Thailand, or 82 lower than Malaysian one. Technological backwardness has been producing low-quality and unstable products in the country, thus limiting the competitiveness of enterprises. This is the consequence of using lagging technology from two or three generations and has not mastered the technology, slow technology innovation of enterprises today. Based on that, the article aims to assess the current state of technological development at Vietnamese enterprises so that to present some recommendations on further development.

\section{Theoretical foundations and research methods}

\section{Theoretical basis}

The concept of technology

According to the UNIDO, technology is the application of science to industry by using research results and processing them systematically and methodically.

Definition provided by the United Nations Economic and Social Commission for Asia and the Pacific (ESCAP) is as follows: Technology is a set of tools and means to transform natural resources and intermediate production resources into consumer goods or other intermediary resources. The tools, means here are understood as "all skills, knowledge, equipment and methods used in manufacturing, service, management and information".

On the top of all above, the Law on Science and Technology (2000) defines: "Technology is a set of methods, processes, skills, know-how, tools, means used to transform resources into products".

Thus, we can generalize that technology is a set of tools, methods and means to transform resources into products.

The concept of enterprise

Article 4 of the 2005 Enterprise Law of Vietnam states the following: "enterprise is an economic organization which has its own name and property, has a stable transaction office and has registered business in accordance with the law for the purpose of carry out business activities".

Business, generally speaking, can be also understood as a community of people who produce wealth. It is born, grows, has failures, has successes, sometimes surpasses critical times, and vice versa, it may be time to stop production, it also sometimes dies due to difficulties it is not able to overcome. 


\section{TECHNOLOGICAL CURRENT STATUS OF VIETNAMESE}

An enterprise can be also viewed as a unit of production organization in which people combine different factors of production, through the efforts of this company's employees, to sell at the market of goods or services so that to receive the difference between the selling price of a product and its immediate cost (Truong, 2015).

Thus, an enterprise is understood here as a production organization being engaged in production, supply and sale of products or services, on the basis of maximizing the interests of consumers, through which maximum benefits for the owner are achieved in parallel to reaching a rational combination of social objectives.

Criteria for assessing the current state of technology at enterprises are as follows:

According to the Ministry of Science and Technology's Circular No. 04/2014, the criteria for assessing the technological level of an enterprise include:

(1) Criteria for technological equipment, including:

Level of wear and tear

Capital intensity of the equipment

Level of equipment innovation

Level of automation

Synchronization of equipment

Rate of raw material cost in production

(2) Criteria related to human resources

(3) Criteria related to information

(4) Criteria related to organization and management

Managing device performance

Development of product innovation

Production management system

Environmental protection

In this study, we only limit to some of the criteria to reflect the current state of technology of the enterprise, namely, the criteria of technology transfer and technological innovation as reflected in the novelty of a product.

\section{Research Methods}

\section{Research data:}

The article uses secondary data sources, namely those on the obstacles to business activities of enterprises, main technological sources of Vietnamese enterprises, novelty of the research products, percentage of the enterprises performing improvements and technologyrelated research etc. Also, data was used from the Global Competitiveness Index of Technology on the selected ASEAN countries (2015-2016), CIEM, GSO and also DOEconducted the Enterprise Competitiveness and Enterprise Technology Survey in Vietnam (2013) and finally the data from the WEF Global Competitiveness Report, 2015-2016.

\section{Research methodology:}

The article mainly uses the descriptive statistics methodology combined with analytical, evaluation and synthesis methods to highlight the technological situation of Vietnamese enterprises before the requirements of international integration were put forward. 


\section{Results and evaluation}

\section{Results}

According to the data reported in the 2016 Statistical Yearbook, as of 31/12/2015, there were 442.5 thousand enterprises operating in the country, this number is $10 \%$ higher as compared to 2014. The distribution by types of enterprises in this statistics was as follows: non-state enterprises increased by $10.2 \%$; foreign direct investment enterprises increased by $8.1 \%$; state-owned enterprises decreased $7 \%$, mostly due to equitization of enterprises. According to the United Nations Industrial Development Organization (UNIDO) data, when it comes to technological standards, Vietnamese enterprises are still mostly low-tech. In 2010, the proportion of enterprises operating in low-tech industries (food processing, textiles, wood and the like) accounted for 46.9\%; in 2014 their number went slightly down - to 44.2\%. Meanwhile, firms operating in high-tech industries are still in the minority, though their number has been gradually rising - from $15.8 \%$ in 2010 to $17.3 \%$ in 2014 . According to the survey conducted by the Central Institute for Economic Management, the General Statistics Office and Copenhagen University back in October 2014, one of the major obstacles to business operations of Vietnamese companies is lack of machinery and devices.

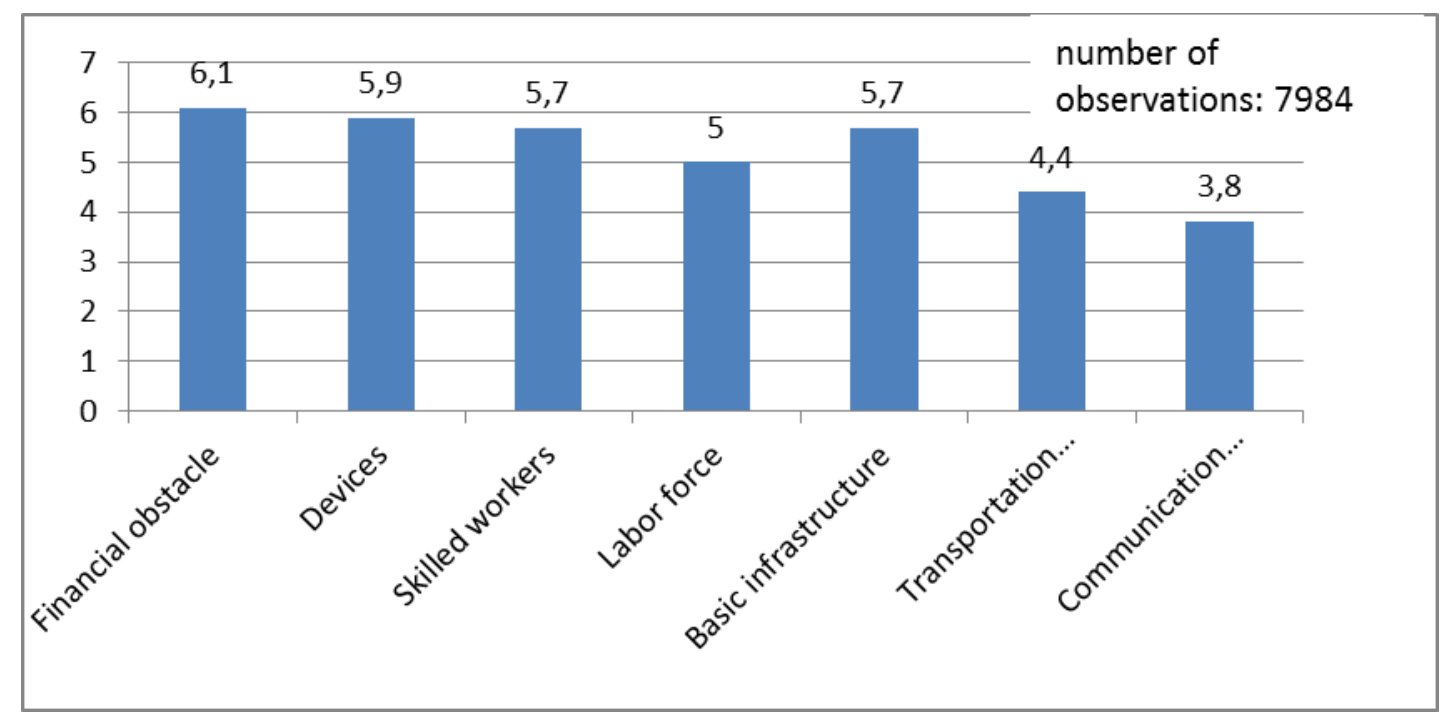

Figure 1. Obstacles (in terms of lack of various factors) to business operations of Vietnamese enterprises

(Source: CIEM, GSO, DOE, Enterprise Competitiveness and Technology Survey Program in Vietnam, 2013, p.18)

The answers were evaluated on the scale from 1 of 10 . Among the seven barriers to business operations of Vietnamese enterprise, the second largest in terms of influence is the factor of machinery and equipment (5.9 points), only financial obstacles got higher score (though slightly higher -6.1 ). This shows that technologies' application at the operational level is one of the key problems faced by Vietnamese enterprises (Trinh The Truyen et al., 2016). At the deeper level, this tech-related obstacles stem from science and technologies' use in business activities of enterprises. 


\section{TECHNOLOGICAL CURRENT STATUS OF VIETNAMESE}

This, first of all, concerns the issue of technology transfer. An important way to achieve innovations and advanced development of enterprise is transfering technology between the enterprises operating in the same sector. This positive effect can be achieved through the spread of knowledge on new production methods, processes, or through the purchase of advanced machinery and equipment produced by more qualified organizations (CIEM, GSO, DOE, 2014, p. 20). According to the survey carried out by CIEM and other agencies, Vietnamese enterprises mainly transfer technology from domestic enterprises.

According to the data in the table below, most of the enterprises receive technology transfers from other domestic enterprises (66\% of all cases). This shows that technology transfer of enterprises takes place mainly domestically. Therefore, domestic enterprises have very little chances to approach and learning from foreign enterprises from the same or similar sectors.

Table 1. Main technology sources for Vietnamese enterprises

(Source: CIEM, GSO, DOE, Enterprise Competitiveness and Technology Survey Program in Vietnam, 2013 survey results, p. 23)

\begin{tabular}{|c|c|c|}
\hline Transfer Sources & Total & Ratio (\%) \\
\hline Vietnamese enterprises, same sector & 857 & 10,87 \\
\hline Vietnamese enterprises, other sectors & 4.355 & 55,26 \\
\hline Foreign enterises, same sector & 1.270 & 16,12 \\
\hline Foreign enterprises, other sectors & 1.399 & 17,75 \\
\hline Total & 7.881 & 100,00 \\
\hline
\end{tabular}

The second important factor is technological innovations (or innovative technologies). This is an important activity which aims to help enterprises improve their ability to innovate at the higher technological levels. Enterprises can invest in new research and development activities or improve and develop technologies that are not yet available at their market. In other words, businesses can make improvements based on their research activities, focusing on improving the existing technologies, using the knowledge and techniques developed independently. In the course of the CIEM's 2014 survey, the total of 8010 enterprises were surveyed, and only 514 enterprises (6.4\% of the total number) were investing in some form of research and development activities. In these activities, only $4 \%$ were rated as new as compared to the world level, 53.2\% were considered new as compared to the local market, and $42.9 \%$ were rated as new to the business itself. 


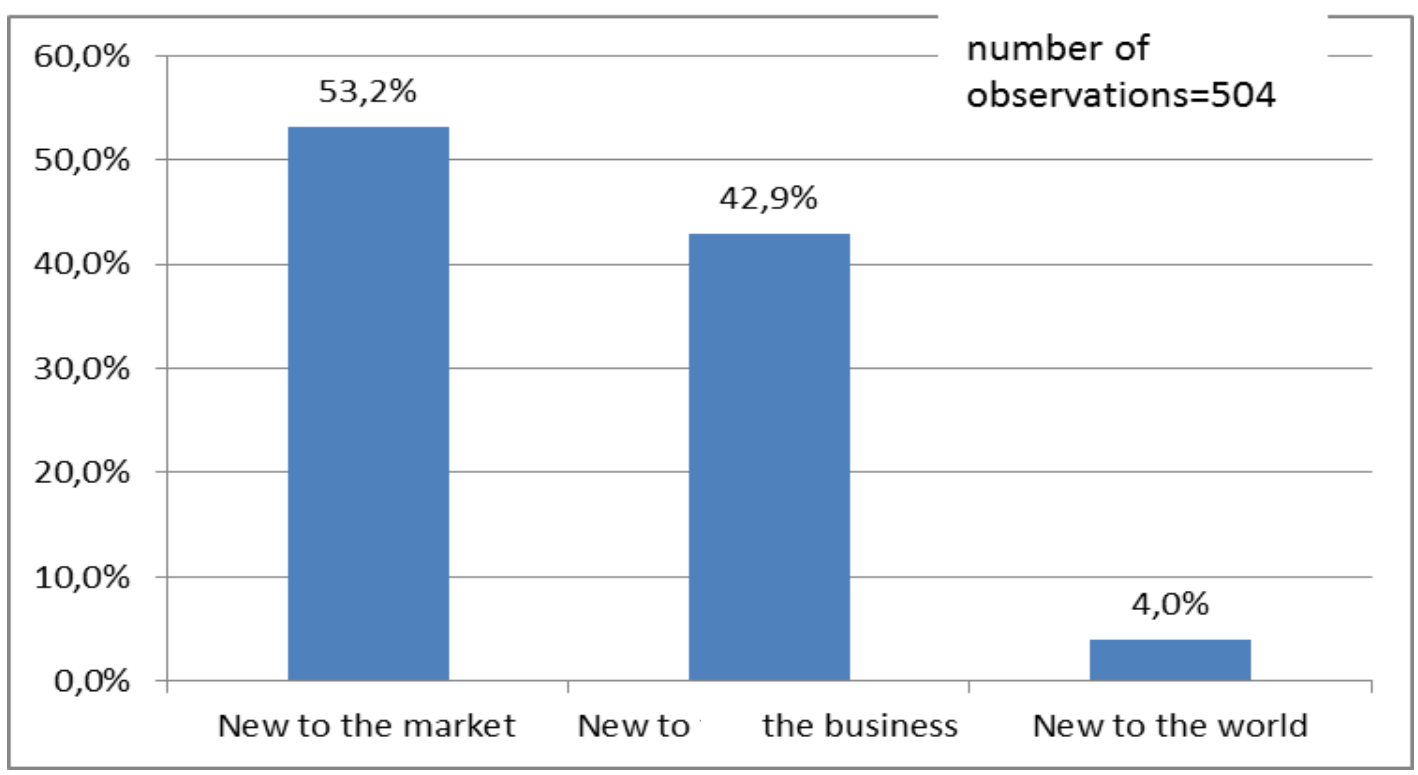

Figure 2 - The novelty level of the developed research product

(Source: Enterprise Competitiveness and Technology Survey Program in Vietnam, 2013, p. 41)

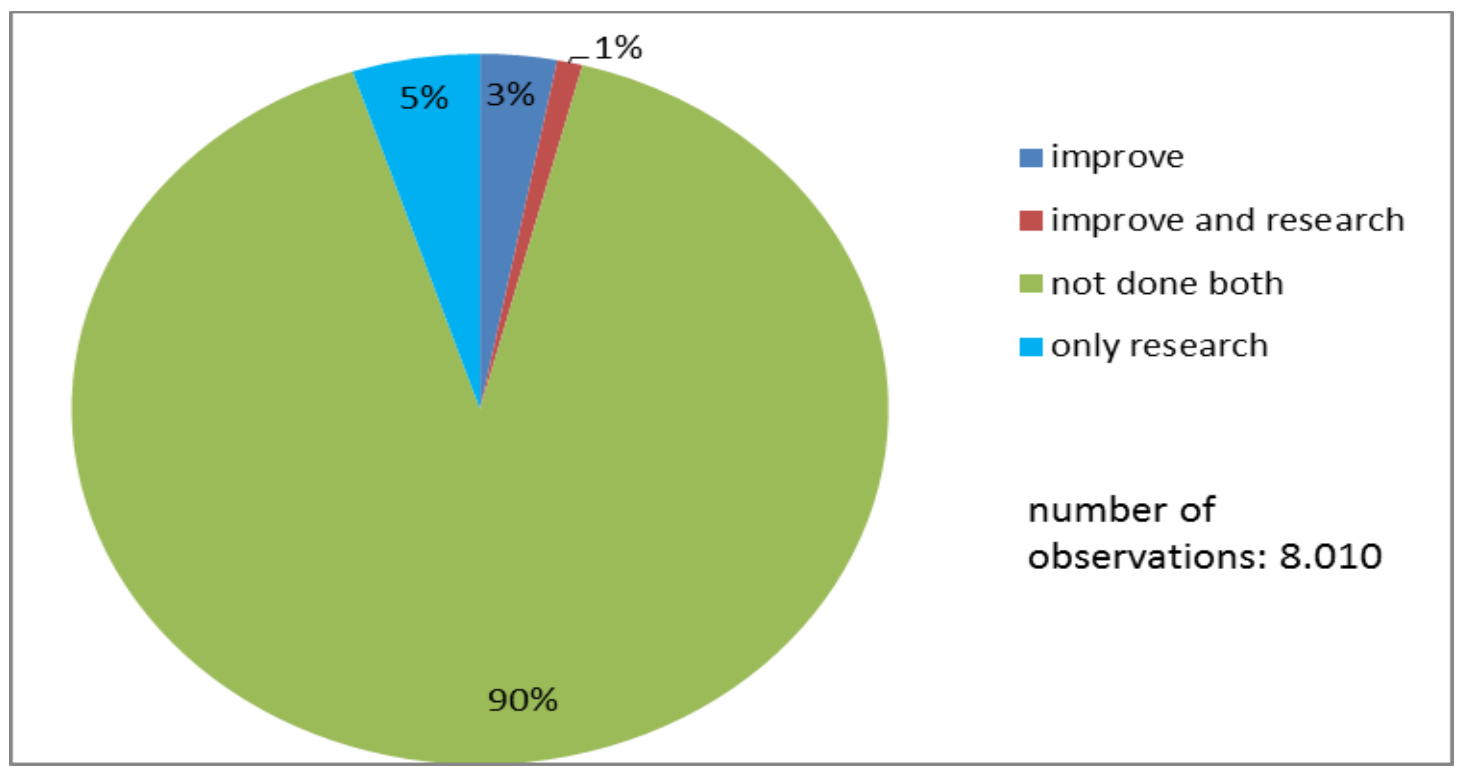

Figure 3 - Percentage of enterprises implementing innovations and/or engaged in tech-related research

(Source: Enterprise Competitiveness and Enterprise Technology Survey Program in Vietnam, 2013, p. 44)

The level of technological innovation at Vietnamese enterprises is mostly limited to the level of technological innovation as compared to other similar products available at the local market, and even provided there are sufficient investments in an innovative technology for the local market, chances of radical renewal are still rather limited. In addition, the study also shows that innovations carried out by enterprises are mainly performed at the research level 


\section{TECHNOLOGICAL CURRENT STATUS OF VIETNAMESE}

(for further implementation by the same enterprises only). The share of enterprises engaged in both research and innovations' implementation activities is extremely small, about $1 \%$ only, whereas $90 \%$ of all studied enterprises perform neither improvement, nor R\&D.

Table 2. Global Competitiveness Indices of Technology of the selected ASEAN countries, 2015-2016

(Source: WEF Global Competitiveness Report 2015-2016)

\begin{tabular}{|c|c|c|c|c|c|c|c|c|c|c|}
\hline \multirow[b]{2}{*}{ Criteria } & \multicolumn{2}{|c|}{ Vietnam } & \multicolumn{2}{|c|}{ Malaysia } & \multicolumn{2}{|c|}{ Singapore } & \multicolumn{2}{|c|}{ Thailand } & \multicolumn{2}{|c|}{ Indonesia } \\
\hline & Score & Rating & Score & Rating & Score & $\begin{array}{c}\text { Ratin } \\
\mathrm{g}\end{array}$ & Score & Rating & Score & Rating \\
\hline \multicolumn{11}{|c|}{ On technological readiness } \\
\hline $\begin{array}{l}\text { Availability of } \\
\text { the latest } \\
\text { technologies }\end{array}$ & 4 & 112 & 5,7 & 30 & 6,2 & 13 & 4,7 & 70 & 4,8 & 68 \\
\hline $\begin{array}{l}\text { Geting } \\
\text { technology at the } \\
\text { enterprise level }\end{array}$ & 3,9 & 121 & 5,6 & 23 & 5,7 & 16 & 4,9 & 53 & 5,1 & 41 \\
\hline $\begin{array}{l}\text { FDI and } \\
\text { technology } \\
\text { transfer }\end{array}$ & 4,2 & 81 & 5,5 & 5 & 6 & 2 & 4,9 & 28 & 4,6 & 54 \\
\hline \multicolumn{11}{|c|}{ Improvement criterias } \\
\hline $\begin{array}{l}\text { Improved } \\
\text { capacity }\end{array}$ & 3,8 & 81 & 5,5 & 7 & 5,1 & 19 & 4,1 & 54 & 4,7 & 30 \\
\hline $\begin{array}{l}\text { Quality of } \\
\text { scientific } \\
\text { research } \\
\text { institutions } \\
\end{array}$ & 3,3 & 95 & 5,3 & 20 & 5,6 & 22 & 4 & 53 & 4,3 & 41 \\
\hline $\begin{array}{l}\text { Businesses invest } \\
\text { in } R \& D\end{array}$ & 3,3 & 57 & 5,3 & 8 & 5 & 11 & 3,5 & 45 & 4,2 & 24 \\
\hline $\begin{array}{l}\text { Cooperation } \\
\text { between } \\
\text { universities and } \\
\text { enterprises } \\
\text { regarding } \\
\text { technology } \\
\text { transfer }\end{array}$ & 3,3 & 92 & 5,3 & 12 & 5,6 & 5 & 4 & 45 & 4,5 & 30 \\
\hline $\begin{array}{l}\text { Purchases of new } \\
\text { technologies by } \\
\text { the government }\end{array}$ & 3,9 & 28 & 5,3 & 3 & 5 & 4 & 3,1 & 90 & 4,2 & 13 \\
\hline $\begin{array}{l}\text { Availability of } \\
\text { scientists and } \\
\text { engineers }\end{array}$ & 3,9 & 75 & 5,4 & 5 & 5,1 & 11 & 4,3 & 47 & 4,6 & 34 \\
\hline $\begin{array}{l}\text { Inventions, } \\
\text { Licenses for } \\
\text { inventions, } \\
\text { technical } \\
\text { applications / per } \\
1 \text { mln people } \\
\end{array}$ & 0,2 & 91 & 11,6 & 33 & 127 & 14 & 1,3 & 66 & 0,1 & 102 \\
\hline
\end{tabular}

\section{Evaluation}

From the above analysis, the technological level of Vietnamese enterprises is still very low. Up to $95 \%$ of all studied small and mid-sized enterprises use technologies which are 
already 3-4 years old as compared to the world level. Thus, the R\&D capacity of these enterprises is very limited (Dao Thanh Truong, 2015). Classification of technologies according to the criteria of the United Nations Industrial Development Organization (UNIDO) shows that Vietnamese enterprises are still mainly underperforming in this regard. The absolute majority of Vietnamese enterprises are still operating in the sectors and subsectors of low technological intensity. Meanwhile, enterprises operating in technologically more intensive industries together comprise still much less than the quarter of all Vietnamese enterprises (Luong Minh Huan, 2016). Therefore, technological backwardness becomes one of the core causes behind huge energy wastage and thus, also higher costs for the enterprises themselves. Technological and technical backwardness together also lead to lower and limited competitiveness as prices for domestic products are often higher than those for the products imported from abroad. Besides, the technological development level of Vietnamese enterprises is relatively low evem when compared only within the context of ASEAN alone, see the following table.

According to the data presented in Table 2, the index of competitiveness related to technologies and innovations of Vietnam is only average, much lower than the indices of the selected countries in the same region, such as Malaysia, Thailand, Singapore, and Indonesia. More specifically, availability of the latest technologies for Vietnamese enterprises reached only 4 scores, thus, by this position the country is ranked 112 out of 140 evaluated countries. This shows that the current level of technologies within enterprises is very low, businesses are using mostly outdated technologies and a very modest number of innovations.

In terms of capacity improvement, Vietnam got only 3.8 points, and thus is ranked \#81, the criteria for research and development, the level of buying new technologies by the government etc. are all lower than the levels in other countries of the same region.

In addition, such indicators as the quality of scientific research institutions, the level of companies investing in $\mathrm{R} \& \mathrm{D}$, cooperation between universities and enterprises in terms of technology transfer, availability of scientists and engineers also got very low scores as compared to other ASEAN members. Thus, with the current low technological level, Vietnamese enterprises are facing many other difficulties on the way to international integration. This is easy to see because Vietnamese enterprises have limited capital, low labor productivity, and also low level of technological equipment. Thus, when it comes to international integration, Vietnamese enterprises will face a lot of competition, in which technology is already now becoming a serious barrier to their development. The current situation with low technological development of Vietnamese enterprises has been predetermined by the following reasons:

First of all, Vietnamese enterprises are mostly small or mid-sized enterprises. Thus, they often lack capital, so it is difficult for them to purchase expensive equipment or newest technologies for production. In addition, access to technologies for such enterprises is often, connected with a range of other difficulties, since technological innovations may require serious changes in the organizational structure, human resource retraining, more access to science and technologies and more time spent on them etc. All these activities are hardly the priority for Vietnamese small and mid-sized businesses these days.

Secondly, technologies' transfer between enterprises is difficult due to the lack of sufficient information on technology markets and management of technology import-export processes as well as on the related technological standards. And since there is hardly any 


\section{TECHNOLOGICAL CURRENT STATUS OF VIETNAMESE}

monitoring over these processes, outdated technologies still heavily imported into Vietnam from other, more developed countries.

Third, in the process of technological innovations' introduction, enterprises often become confused when it comes to selecting a proper technology, equipment, supplying partners, transferring contracts etc. This is because they lack experience in this field and also because there are very limited options in terms of education and awareness for them.

Fourth, there is a huge gap between enterprises on the one side and scientific and technological research institutions on the other, since these sides hardly communicate. This is one of the central reasons why domestically developed innovations are seldom transferred to the local enterprises.

Fifth, the level of human resources' development and their quality at local enterprises are very limited, this means local staff finds it hard to adapt to innovations and newer technologies.

\section{Conclusion}

Science and technology are necessary activities for the production processes at enterprises. At present, there are many limitations in the process of technological innovations' implementation. Vietnam applies very little promotion concerning the role of science and technology in economy and society. Therefore, in order to promote the role of science and technology for enterprises, we put forward the following recommendations:

From the macro perspective, the central government should set priorities concerning the long-term economic and social development, ensuring adequate supply of resources for the development of innovative systems, and also ensuring that state-run organizations function well and that parts of the innovation system are interlinked, thus creating a unified whole.

Enterprises should coordinate their innovative efforts with scientific and technological research agencies and organizations so that the latter could help supply enterprises with most advanced machinery and equipment.

Enterprises should be more active in seeking for information on technological market development, procedures related to technology transfer, quality of various technologies etc. Knowledge and awareness would help them make more appropriate and effective technological choice.

Enterprises need to prepare their own human resources to accessing new technologies. In order to facilitate for enterprises' development on the basis of technological development, it is necessary to enhance human resources via standardized training in technology. Such trainings should be matching the actual production needs as they are important for the creation of new opportunities and formation of a more appropriate environment that maximizes the creative capacity of the workforce through better professional training.

\section{References}

CIEM, DOE, GSO (2014). Competitiveness and enterprise-level technology in Vietnam through the results of the 2013 survey, Finance Publishing House.

Enterprise Law 2005: http://www.moj.gov.vn/vbpq/lists/vn\%20bn\%20php\%20lut/ view_detail.aspx?itemid=16744 
General Statistics Office (2016). Statistical Yearbook 2015: http://www.gso.gov.vn/default.aspx ?tabid=512\&idmid=\&ItemID=16051

Luong Minh Huan, Nguyen Thi Thuy Duong (2016). The situation of investment in science and technology in Vietnam, Journal of Science and Technology of Vietnam, 9

Law on Science and Technology as of 2000: https://thuvienphapluat.vn/van-ban/Cong-nghe-thongtin/Luat-Khoa-hoc-va-Cong-nghe-2000-21-2000- QH10-46449.aspx

Ministry of Science and Technology (2014). Circular guiding the evaluation of production technology No. 04/2014 / TT-BKHCN. https://thuvienphapluat.vn/van-ban/Cong-nghe-thong-tin/Thongtu-04-2014-TT-BKHCN-danh-gia-trinh-do-cong-nghe-san-xuat-Bo-Khoa-hoc-va-Cong-nghe227009.aspx

National Economics University (1998). Technology and Technology Management, Science and Technology Publishing House, Hanoi, 8.

Trinh The Truyen, Nguyen Anh Tuan, Tran Thi Kim Dao (2016). Vietnamese enterprises with technological challenges when entering the international market, ASEAN Economic Community (AEC). ISBN 978-604-73-4695-0, tr 927, University of Economics and Law.

Dao Thanh Truong (2015). Situation of STI system in Vietnamese enterprises, Journal of Planning and Evaluation, Policy Research and Management, 31(2): 33-34.

Word Economic Forum: The Global Competitiveness Report 2015-2016, http://reports.weforum.org/ global-competitiveness-report-2015-2016/

Paper submitted 06 December 2017

Paper accepted for publishing 21 February 2018

Paper published online $\quad 30$ March 2018 